\title{
UJI EFEKTIVITAS BEBERAPA JENIS TANAMAN SEBAGAI PESTISIDA NABATI TERHADAP HAMA GUDANG Callosobrunchussp
}

\author{
Yustina M.S.W. Pu'u' ${ }^{1}$, Adrianus A Janggo² \\ Yus_puu@yahoo.com \\ Program Studi Agroteknologi, Fakultas Pertanian-Universitas Flores
}

\begin{abstract}
This research aimed to determine the effectiveness of pesticide plant leaves to the growth of warehouse pest (Callosobrunchussp)and plant extracts that causes the highest mortalityof warehousepests (CallosobrunchusSp).

The design used in this study was a Complete Randomized Block Design (CRBD) with the treatments used are PN0 (aquades), PN1 (Leeksextract), PN2 (extracts of Tagetes), PN3 (leaves Lemongrass Extract). Variable observations in this study are the toxins, contact poisons, nerve poison, repelen and antioviposit.

The results showed that the extract of leaves of Tagetes, Lemongrass and Scallion effect on the growth of pest warehouse (Callosobrunchus sp) on observations of Toxins, contact poisons, nerve poison, repelen and antioviposit.Leaves Tagetes extract is the right plant and effective towardsmortalityof warehousepest (Callosobruschus Sp) at $80.89 \%$ of poisons contact, nerve at $84,02 \%$, and $85,05 \%$ of repelen activity, antioviposit at $97,6 \%$.
\end{abstract}

Key words: effectiveness, plantpesticide, Callosobrunchussp

\section{PENDAHULUAN}

Kacang hijau merupakan tanaman pangan yang cukup penting di daerah tropis. Tingkat produksi dan produktivitas kacang hijau secara kuantitas maupun kualitas juga dipengaruhi OPT baik hama, penyakit, dan gulma. Kerusakan yang ditimbulkan dapat terjadi di lapang, panen, dan penyimpanan.

Hama yang menyerang kacang hijau dipenyimpanan salah satunya adalah kumbang CallosobrunchusSp. Gejala serangan Kumbang kacang hijau (Callosobrunchus sp) tampak lubang pada biji-biji kacang hijau yang mengakibatkan lama-kelaman biji 
Yustina: Uji efektivitas beberapa jenis tanaman sebagai pestisida nabati terhadap hama gudang Callosobrunchus sp

tersebut menjadi retak. Menurut

Kartasapoetra (1987), Callosobrunchus

sp mulai menyerang biji sejak di lapang

sampai tempat penyimpanan dan

menyebabkan kehilangan hasil

mencapai $70 \%$.

Upaya pengendalian hama gudang umumnya dilakukan dengan insektisida sintetik berupa fumigan seperti metil bromida dan fosfin (Kim dan Ahn, 2001

dalam Agustin, 2003). Penggunaan insektisida sintetik yang dilakukan sering menimbulkan dampak negatif seperti resistensi, resurgensi, dan ledakan hama sekunder serta terkontaminansi bahan simpanan dalam penyimpanan (Purwandi, 2008).Untuk mengatasi permasalahan tersebut, maka dapat dilakukan upaya pengendalian yang sesuai dengan prinsip PHT salah satunya dengan pemanfaatan pestisida nabati yang berasal dari tumbuhtumbuhan.
Pestisida nabati merupakan senyawa kimia yang berasal dari tumbuhan yang digunakan untuk memberantas organisme pengganggu tumbuhan berupa hama dan penyakit tumbuhan maupun tumbuhan pengganggu (gulma). Pestisida nabati merupakan hasil ekstraksi bagian tertentu dari tumbuhan baik dari daun, buah, biji atau akar. Biasanya bagian tumbuhan tersebut mengandung senyawa atau metabolit sekunder dan memiliki sifat racun terhadap hama dan penyakit tertentu. Beberapa tanaman yang mempunyai potensi sebagai pestisida nabati antara lain tanaman Serai, Bawang Daun dan Tagetes (Menurut Takahashi, 1981).

Serai (Cymbopogonnardus L.) dapat dimanfaatkan sebagai pengusir serangga karena mengandung zat-zat seperti Saponin dan Tanin. Dalam kehidupan sehari-hari sereh digunakan sebagai bumbu dapur. Tanaman sereh 
Yustina: Uji efektivitas beberapa jenis tanaman sebagai pestisida nabati terhadap hama gudang Callosobrunchus sp

wangi merupakan salah satu tanaman penghasil insektisida nabati yang mempunyai kemampuan untuk menurunkan populasi hama. Bagian dari daun sereh wangi dapat menghasilkan bau atau aroma yang tidak disukai oleh hama (Kurniawan, 2007). Ekstrak daun Serai diketahui memiliki sifat insektisidal terhadap hama gudang Callosobrunchus makulatus dan Achantoschelides obtectus (Sylvia dkk, 1994). Konsentrasi ekstrak daun serai 8,5\% menyebabkan mortalitas sebesar $66,67 \%$ dan menghambat aktivitas makan larva $P$. xylostella sebesar $82,66 \%$ pada 10 jam setelah aplikasi (Shahabuddi dan Alam Anshary, 2010).

\section{Prei (Allium porum L) tidak} berumbi dan daunnya lebih lebar dari jenis bawang merah atau putih. Daun dan akar Allium fistulosum mengandung saponin dan tanin, disamping itu daunnya mengandung minyak atsiri (Natawiria,1973). Safitri (2004) menggunakan ekstrak air dan ekstrak etanol bawang daun dalam menghambat pertumbuhan bakteri Streptococcus agalactie, Staphylococcus aureus, dan Escherichiacoli. Pada konsentrasi 20\%, ekstrak bawang daun memiliki aktivitas anti bakteri yang sama dengan ampicilin $5 \mu \mathrm{g}$ terhadap bakteri $S$. agalactie, S. aureus, dan E. coli.

Tagetes berkhasiat sebagai penangkal serangga. Daun Tagetes erecta mengandung saponin dan flavonoida (Luqman, 2011). Hasil penelitian Lia Anisa Marfuah (2009) menunjukkan bahwa ekstrak daun dengan konsentrasi $2.45 \%$ menyebabkan mortalitas ulat daun kubis sebesar 50\%. Ekstrak tagetes konsentrasi 12,5\% mampu menekan perkembangan Meloidogyne SP sebesar 91,94\% (Setiawati et al, 2002). Informasi tentang penggunaan beberapa tanaman seperti Tagetes, Bawang daun dan Sereh sebagai insektisida nabati khususnya bagi petani di Kabupaten Endesampai saat ini belum ada, 
Yustina: Uji efektivitas beberapa jenis tanaman sebagai pestisida nabati terhadap hama gudang Callosobrunchus sp

sehingga penelitian ini dianggap penting dan perlu dilakukan.

\section{METODE PENELITIAN}

\section{Tempat dan Waktu}

Penelitian ini dilaksanakan di

Laboratorium Fakultas Pertanian

Universitas Flores, Jln Sam Ratulangi

Kabupaten Ende. Waktu penelitian dimulai dari bulan September-

Desember 2012.

\section{Bahan dan Alat}

Bahan yang digunakan yaitu imago Callosobrunchus sp, Bawang daun, Daun Tagetes, Daun Sereh, kacang hijau, methanol, dan aqudes. Alat yang digunakan dalam penelitian yaitu pisau, botol, timbangan, cawan Petri, toples plastik, aspirator, pensil, kamera, gelas ukur, kertas label, blender, Rotary evaporator, micro pipet, frezeer, saringan dengan ukuran 100 mesh dan kertas saring weathmen.

\section{Rancangan Penelitian}

Rancangan yang digunakan adalah Rancangan Acak Lengkap (RAL), dengan faktor tunggal yang terdiri dari 4 perlakuan yaitu: PNO (Aquades), PN1 (Ekstrak Bawang Daun), PN2 ( Ekstrak Tagetes), dan PN3 (Ekstrak Sereh). Masing-masing perlakuan diulang sebanyak 5 kali, sehingga terdapat 20 satuan percobaan.

\section{Pelaksanaan Penelitian}

\section{Perbanyakan Callosobruchus sp}

Imago Kumbang kacang hijau diambil, kemudian dipelihara dalam toples plastik yang berisi kacang hijau sebagai pakannya dan dipelihara sampai mendapatkan lagi keturunan F2 dan siap digunakan sebagai bahan perlakuan.

\section{Proses Ekstraksi Tanaman,}

\section{Pembuatan konsentrasi dan Aplikasi \\ Daun Tagetes, Bawang Daun dan Daun serai Daun yang masih segar dicuci bersih, kemudian dikering anginkan selama \pm 2 hari. Daun yang sudah disiapkan dicacah menggunakan}


Yustina: Uji efektivitas beberapa jenis tanaman sebagai pestisida nabati terhadap hama gudang Callosobrunchus sp

parang dan diblender. Daun yang sudah

diblender, diayak dengan menggunakan

saringan 100 mesh untuk mendapatkan

bubuk dan direndam menggunakan

Metanol dengan perbandingan 1:5 (100

gram : $500 \mathrm{cc}$ metanol) sebagai pelarut

selama \pm 24 jam. Setelah itu, disaring

dengan menggunakan kertas weathman.

Ekstrak yang didapat dari penyaringan

perendaman sebanyak $50 \quad \mathrm{ml}$.

Pengeceran bahan aktif dengan

menggunakan aquades dengan

konsentrasi 5\%. Pestisida tersebut

diaplikasikan pada serangga uji dan

kacang hijau, dimana setiap perlakuan

terdiri dari 10 ekor serangga uji.

\section{Variabel Penelitian}

Variabel Penelitian ini adalah Aktivitas racun kontak (\%), Aktivitas repellan (\%), Aktivitas racun syaraf (\%), dan Aktivitas anti oviposisi (\%).

\section{Analisis Data}

Data dianalisis dengan menggunakan analaisis sidik ragam.
Apabila perlakuan menunjukkan pengaruh yang nyata, maka dilanjutkan dengan uji BNT taraf 5\% (Gomez \& Gomez, 1995).

\section{HASIL DAN PEMBAHASAN}

Hasil analisis sidik ragam menunjukkan bahwa ekstrak tanaman Tagetes, Bawang Daun dan serai berpengaruh terhadap perkembangan hama gudang Callosobruchus Sp pada aktivitas Racun Kontak, Racun Syaraf, Repelan dan Anti Oviposisi (Gambar 4.1).

Hasil penelitian menunjukkan bahwa ekstrak daun tagetes menyebabkan mortalitas imago Callosobrunchus sp paling tinggi dibandingkan pada perlakuan ekstrak lainnya yaitu pada racun syaraf sebesar $84,02 \%$, racun kontak sebesar 80,89\%, racun syaraf sebesar $84,02 \%$, repellan $43,19 \%$, dan antioviposisi sebesar 97,6 $\%$. 
Yustina: Uji efektivitas beberapa jenis tanaman sebagai pestisida nabati terhadap hama gudang Callosobrunchus sp

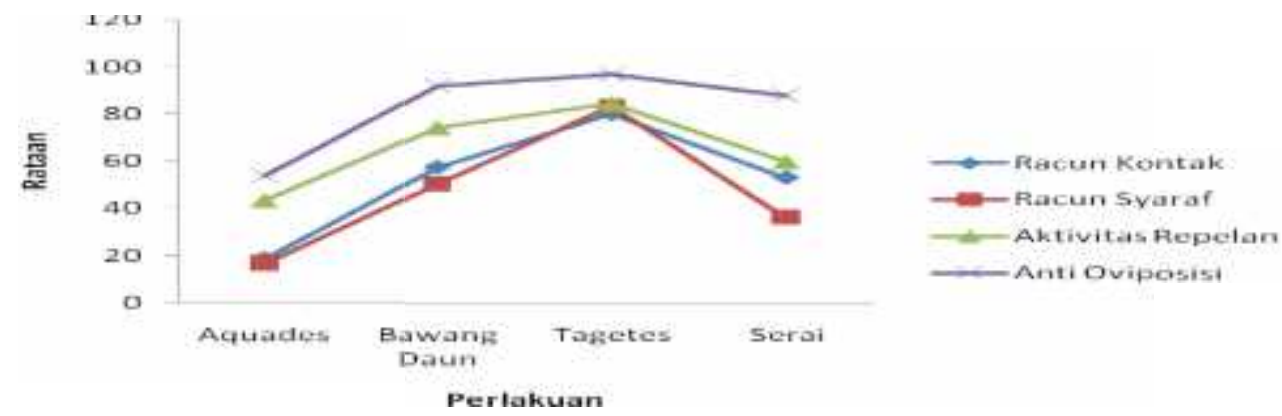

Gambar 4.1 Efektifitas Beberapa Jenis Tanaman Sebagai Pestisida Nabati Terhadap Hama Gudang Callosobruchus Sp Pada Variabel Pengamatan Racun Kontak, Racun Syaraf, Repelan dan Anti Oviposisi.

Hal ini disebabkan karena tagetes dan menembus integumen. Kneblock mengandung bahan aktif seperti (1989) Senyawa saponin bersifat saponin, flavonoid, tanin dan minyak sebagai racun dan antimikroba (jamur, atsiri yang dapat menyebabkan bakteri, virus), bahan aktif yang mortalitas pada imago Callosobrunchus memiliki sifat daya larut lebih tinggi sp (Sutoyo, 1997). Callosobrunschus dalam air akan mudah menembus Sp yang mati menunjukkan perubahan perilaku mulai dari pergerakkannya yang cepat dan lama kelamaan kaku dan bentuknya kakinya melipat. Senyawa lapisan fosfolipid membran sel sehingga lebih cepat mengganggu fungsi fisiologis yang pada akhirnya sel akan mengalami kematian (Soebandrio, 1995 Saponin yang memiliki aktivias racun kontak langsung bekerja ketika terjadi kontak antara serangga dan mengalami perubahan aktivitas mulai dari pergerakannya cepat dan kemudian melambat dan kaku. Senyawa tersebut masuk melalui kutikula, atau trakhea atau langsung mengenai mulut serangga dalam Ariati, 2008).

Senyawa flavonoida yang memiliki fungsi yaitu mempengaruhi fungsi syaraf dengan menghambat enzim kolinesterase, sehingga akan terjadi gangguan transmisi rangsang yang menyebabkan menurunnya koordinasi otot, konvuli dan kematian 
Yustina: Uji efektivitas beberapa jenis tanaman sebagai pestisida nabati terhadap hama gudang Callosobrunchus sp

bagi larva yang berkembang menjadi serangga dewasa (Endah dan Heri, 2000). Ekstrak daun tagetes memiliki aroma yang menyegat. Aroma tersebut terdeteksi oleh serangga Callosobrunchus sp melalui organ penerima rangsang, dan dapat mempengaruhi kunjungan serangga tersebut terhadap kacang hijau yang diberi perlakuan.

Minyak atsiri merupakan senyawa yang pada umumnya berwujud cair, yang diperoleh dari bagian-bagian tanaman dan memiliki aroma yang sangat menyengat, dan dapat mempengaruhi sistem syaraf serta dapat mengusir serangga (Gunawan dan Mulyani, 2004; Sastrohamidjojo, 2004). Komponen utama penyusun minyak atsiri Ocimum gratissimum adalah eugenol, thymol, eraniol, citral, saponin, flavonoida dan tannin dengan bau dan sifat khas dari setiap jenis minyak dapat mempengaruhi sistem syaraf seranggga
(Vieira et al, 2001). Minyak atsiri terdiri dari sepasang enansiomer (R)-sitronelal dan (S)-sitronelal.20) Pada jenis Cymbopogon yang lain (Cymbopogon giganteus chiovenda) mengandung minyak atsiri yang terdiri dari limonen, p-mentha-1,5, 8-trien; $\quad$ 1,2limonenoksida; p-mentha-2, 8-dien-1ol; Dekan-2, 4-dien-1-ol; pmetilasetofenon; trans-p-menta-1, 8dien-2-ol; Decan-2, 4-dienal; isopiperitenol; cis-p.menta-1, 8-dien-2ol; cis carveol; carvone; isopiperitenon; cuminil alkohol; perililaldehid; perilil alkohol (Istifada, S., 1999). Minyak atsiri merupakan senyawa yang pada umumnya berwujud cair, yang diperoleh dari bagian-bagian tanaman dan memiliki aroma yang sangat menyengat, dan dapat mempengaruhi sistem syaraf serta dapat mengusir serangga (Gunawan dan Mulyani, 2004; Sastrohamidjojo, 2004). Komponen utama penyusun minyak atsiri Ocimum 
Yustina: Uji efektivitas beberapa jenis tanaman sebagai pestisida nabati terhadap hama gudang Callosobrunchus sp

gratissimum adalah eugenol, thymol, eraniol, citral, saponin, flavonoida dan tannin dengan bau dan sifat khas dari setiap jenis minyak dapat mempengaruhi sistem syaraf seranggga (Vieira et al, 2001).

Senyawa Tanin mempunyai aroma yang menyengat sehingga serangga tidak berkunjung dan menghindari dari bahan aktif (Laksamanahardja, 2002) Ekstrak daun tagetes, bawang daun dan serai memiliki aroma yang sangat menyengat, Dan dapat mempengaruhi sistem syaraf serta dapat mengusir serangga Callosobruschus Sp. Senyawa saponin bersifat sebagai racun dan antimikroba (jamur, bakteri, virus), bersifat antioksidan. Bahan yang bersifat sebagai anti bakteri dapat menganggu proses fisiologis dan menghambat terbentuknya komponen sel seperti sintesis dinding sel, membrane sitoplasma, sintesis protein dan sintesis asam nukleat (Soebandrio, 1995 dalam Ariati, 2008).

Senyawa alkaloid dan saponin yang memiliki efek toksik, dan merupakan bahan organik yang mengandung nitrogen sebagai bahan dari sistem heterosiklik, alkaloid bersifat basa, larut dalam air dan diketahui dapat menghambat sintetis protein dan merusak fung sehingga serangga Callosobrus tidak meletakkan telurnya pada kacang hijau yang diberi perlakuan (Tobing, 1989).

Serangga tersebut akan selalu memeriksa inangnya kembali sebelum bertelur, dengan berkurangnya bahan aktif yang disebabkan oleh penguapan, maka inangnya telah dianggap aman, sehingga proses peletakkan telur akan dilakukan. Pengamatan aktivitas anti oviposisi dimana Callosobrunchus sp melakukan pengenalan habitat dan mencari inang untuk bertelur namun 
Yustina: Uji efektivitas beberapa jenis tanaman sebagai pestisida nabati terhadap hama gudang Callosobrunchus sp

inang yang ditemukan tidak cocok, sehingga Callosobrunchus sp mencari inang alternatif untuk meletakkan telur.Telur diletakkan pada dinding toples, tidak pada kacang hijau.

\section{Mortalitas Callosobruschus Sp pada}

\section{Aktivitas Racun Syaraf}

Hasil sidik ragam menunjukkan bahwa perlakuan ekstrak daun tagetes, bawang daun dan serai memiliki aroma yang sangat menyengat, dan dapat mempengaruhi sistem syaraf serangga Callosobruschus $\quad \mathrm{Sp} \quad$ karena mengandung senyawa Saponin, flavonoidadan minyak atsiri. Pengamatan serangga Callosobruschus Sp untuk racun syaraf dilakukan selama 3 jam selama 2 hari memperlihatkan bahwa aktivitas racun syaraf berpengaruh secara nyata pada perlakuan PN2 (daun Tagetes) lebih efektif menurunkan aktivitas repelan Callosobruschus Sp 84,02\% sedangkan untuk K0 tidak menurunkan aktivitas repelan Callosobruschus Sp 16,64\%., hal tersebut diketahui terjadi peningkatan mortalitas serangga Callosobruschus sp akibat racun syaraf.

\section{Aktivitas repellan Callosobruschus Sp}

Hasil analisis statistik dari tabel 4.1 diatas memperlihatkan bahwa perlakuan PN2 (daun Tagetes) lebih efektif menurunkan aktivitas repelan CallosobruschusSp 14,95\% sedangkan untuk K0 tidak menurunkan aktivitas repelan Callosobruschus Sp 56,81\%.

\section{Anti Oviposisi Callosobruschus Sp}

Hasil analisis statistik dari tabel 4.1 diatas memperlihatkan bahwa perlakuan PN2 (daun Tagetes) lebih efektif menurunkan aktivitas bertelur Callosobruschus Sp 92,8\% sedangkan untuk K0 tidak menurunkan aktivitas bertelur Callosobruschus Sp53,6\%. Hal ini terjadi karena pengaruh senyawa aktif yang terkandung pada tanaman Tagetes, Bawang daun dan serai memiliki perbedaan bahan aktif. 
Yustina: Uji efektivitas beberapa jenis tanaman sebagai pestisida nabati terhadap hama gudang Callosobrunchus sp

\section{Kesimpulan}

1. Ekstrak Daun Tagetes, Daun Serai

Dan Bawang Daun berpengaruh terhadap perkembangan hama gudang Callosobrunchussp pada

Racun Kontak Aquades (PN0)

18,70\%, Bawang Daun (PN1)

$58,08 \%$, Tagetes (PN2) 80,89\%,

Serai (PN3) 53,69\% sedangkan

untuk Racun Syaraf Aquades (PNO)

16,64\%, Bawang Daun (PN1)

50,84\%, Tagetes (PN2) 84,02\%,

Serai (PN3) 36,65\%, untuk aktivitas

Repelen Aquades (PN0) 43,19\%,

Bawang Daun (PN1) 74,85\%,

Tagetes (PN2) 85,05\%, Serai (PN3)

60,33\% dan Anti Oviposisi Aquades

(PN0) 53,6\%, Bawang Daun (PN1)

92,8\%, Tagetes (PN2) 97,6\%, Serai

(PN3) $88,4 \%$.

2. Ekstrak Daun Tagetes merupakan tanaman yang tepat dan efektif terhadap mortalitas hama gudang CallosobruschusSp pada racun kontak sebesar 80,89\%, Racun

Syaraf sebesar 84,02\%, aktivitas

repelen sebesar 85,05\%, dan Anti

Oviposisi sebesar 97,6\%.

\section{Ucapan Terima Kasih}

Pada kesempatan ini penulis ingin mengucapkan terima kasih kepada semua pihak yang telah membantu dengan caranya masing-masing dalam melengkapi tulisan ini.

\section{DAFTAR PUSTAKA}

Croccidolonia Binotalis. 1993. Proseding Seminar Hasil Penelitian Dalam Rangka Pemanfaatan Pestisida Nabati. Bogor.

Kurniawan. 2007. Kandungan Tanaman Sereh, Balai Penelitian Tanaman Rempah dan Obat. Bogor.

Luqman. 2011. Kandungan Tanaman Tagetes. Yogyakarta.

Mangundiharjo, $1978 . \quad$ Telur Callosobruchus sinensis. Diakses melalui hhtp://pustaka.bogor.net

Natawiria, 2007. Kandungan Tanaman Bawang Prei. Bogor.

Purwandi. 2008. Gejala Awal Serangan Lalat Buah. Balai Penelitian Tanaman Rempah dan Obat. Bogor.

Pustekom, 2005. Klasifikasi Kumbang Hijau. Balai Besar Penelitian dan Pengembangan.

Supeno, A. 2005. Identifikasi Ketahanan Varietas Kacang Hijau Terhadap Infestasi Hama Gudang Callosobronchus chinensis (L). Jakarta: Buletin Teknik Pertanian. 